Article

\title{
Structural Relationship and Influence between Open Innovation Capacities and Performances
}

\author{
Kwangsoo Shin ${ }^{1}$, Eungdo Kim ${ }^{1}$ and EuiSeob Jeong ${ }^{2, *}$ \\ 1 Department of Biomedical Convergence, College of Medicine, Chungbuk National University, \\ Chungdae-ro 1, Seowon-gu, Cheongju-si, Chungbuk 28644, Korea; \\ sksidea@chungbuk.ac.kr (K.S.); edkim@chungbuk.ac.kr (E.K.) \\ 2 Korea Institute of Science and Technology Information (KISTI), Seoul 02456, Korea \\ * Correspondence: esjng@kisti.re.kr; Tel.: +82-2-3299-6132
}

Received: 24 June 2018; Accepted: 3 August 2018; Published: 7 August 2018

check for updates

\begin{abstract}
Previous studies related to open innovation have presented piecewise implications in relation to various knowledge management capacities. The study published by Lichtenthaler and Lichtenthaler in 2009 presented a model that combines the various open innovation capacities of firms in view of a mix of knowledge management, dynamic capability and absorptive capacity. Despite these efforts, there have been few empirical studies on the relationships among capacities, or between capacities and performance from an integrated perspective. Therefore, this study seeks to clarify the relationships among knowledge capacities and between knowledge capacities, technological innovation and financial performance at the firm level. Our findings are that the transformative, connective, inventive and absorptive capacities both directly and indirectly affects technological innovation performance; and innovative and desorptive capacities are the key factors connecting technological innovation to financial performance. This study provides managerial implications for the balanced development of the various knowledge capacities and the improvement of technological innovation and financial performance for firm knowledge managers.
\end{abstract}

Keywords: open innovation; knowledge capacity; knowledge management; technological innovation performance; financial performance; biopharmaceutical industry

\section{Introduction}

Since Chesbrough [1], the open innovation approach has become an important strategy that links a firm's knowledge capacities and performance. The open innovation is defined as a "systematical strategy relying on a firm's capabilities of internally and externally carrying out the major technology management tasks along the innovation process" [1]. This is closely related to how the firm's innovation process is internally and externally captured from the perspective of the "knowledge-based view." Understanding complex business activities from a knowledge-based view can provide a useful basis for developing a firm's technological innovations [2,3]. This causes business strategies to aim for the goal of acquiring and utilizing necessary knowledge, represented as business activities and further to close the gap between the firm's current and required knowledge capacities.

Previous studies have divided open innovation into three types of inside-out, outside-in and coupled and have in part proved that knowledge capacities are required differently for each type [4-6]. The firm's knowledge capacities are closely related not only to intellectual property (or the knowledge base) but also to the capability to implement the innovation process [7]. In this view, scholars have clearly distinguished these approaches as knowledge implementation strategies for knowledge exploration and exploitation, sometimes explicitly mentioning the need to retain internal and external knowledge as strategic resource [8-10]. Lichtenthaler and Lichtenthaler [11] introduced the concept of 
integrating six firm's knowledge capacities by combining these retention, exploration, exploitation and internal and external firm activities in open innovation systems by applying the laws of biological evolution. Nevertheless, these discussions have been conceptually presented and have not been studied empirically. In particular, the relationships among the various knowledge capacities and the relationships between these knowledge capacities and performance has not been studied.

Therefore, this study examines the structural relationship and impact between the six open innovation knowledge capacities proposed by Lichtenthaler and Lichtenthaler [11] and technological innovation and financial performance. For analysis, this research used eight study variables, including six knowledge capacity variables and two performance variables and three control variables derived from Medtrack as well as PASTAT database. Indicators of patents, products and technology transfers, revenue to measure a firm's knowledge capacities and performances are used. Furthermore, considering the evolutionary characteristics of open innovation, this study adopts a hierarchical structural equation model to emphasize sequences of knowledge capacities and performances, in line with Yun, Won and Park [12]. This approach is important in that it enables the measurement of causality and direct/indirect effects between capacities and performances in an integrated open innovation framework.

This study focuses on the biopharmaceutical industry. The open innovation strategy is significant for biopharmaceutical firms. First, technological innovation in the biopharmaceutical industry requires a longer R\&D period than other industries and huge costs are involved [13]. Therefore, biopharmaceutical firms strategically need an open innovation to maximize performance while lowering R\&D risks. Second, due to the cumulative nature of biopharmaceutical technology, firms have difficulty in developing various technologies. On the other hand, it is necessary to integrate a biopharmaceutical technology with other various complementary technologies for technological innovations. Therefore, biopharmaceutical firms should not only develop their own technology internally but also cooperate with other external organizations to enhance it. Therefore, it is important for biopharmaceutical firms to understand the relationships and influences between a firm's knowledge capacities and its performance with an open innovation framework.

This study provides managerial implications for knowledge managers of biopharmaceutical firms and contributes to the empirical implementation and validation of the conceptual model integrated in Lichtenthaler and Lichtenthaler [11]. The remainder of the paper is organized as follows: the next section provides an explanation about open innovation frameworks and hypotheses for empirical test. Section 3 presents a description of the data sources, variable definitions and analytical model. Section 4 presents the estimation results and discusses them. Finally, this study concludes with Section 5 .

\section{Theories and Hypotheses}

The knowledge-based view in strategic management emphasizes knowledge as a resource and technological innovation by exploitation and exploration as a dynamic capability among various resources [14]. The combinative perspective of resource-based and dynamic capabilities in the knowledge-based view helps managers to understand and explain most of the complex business phenomena they encounter and to expand the firm's boundaries. In particular, in high-tech industries, firm's competitive advantage is directly related to continuous technological innovations. Thus, high-tech firms should build strongly on inter-organizational knowledge creation process through open innovation as well as internal knowledge creation process [8].

The firm's knowledge is created by sustained interaction between internal tacit and explicit knowledge. While new knowledge is developed by individuals, organizations such as firms play a critical role in clarifying and expanding that knowledge. Nonaka [15] suggested frameworks for managing the dynamic aspects of the organizational knowledge creation process, comprising four dynamic processes of combining both tacit and explicit knowledge. Nonaka and Toyama [16] emphasized that knowledge is context-specific; thus, the knowledge creation process is necessarily 
context-specific in terms of time, space and relationships with others. Superior technological innovations achieved by these knowledge creation processes of firms represent significant strategic assets [17].

Along with this internal knowledge creation process, open innovation emphasizes various types of cooperation with external organizations for technological innovations. Gassmann, Daiber and Enkel [18] argued that open innovations can be classified three types according to core processes: (1) inbound open innovation through outside-in processes; (2) outbound open innovation through inside-out processes; (3) mixed open innovation; their study involved a coupled process using interviews, questionnaires and participating observations of 124 companies. Open innovation is nurtured by different research traditions: "collaborative innovation" from strategy and innovation management research; "absorptive capacity" from the knowledge-based view; and "market orientation" from marketing research [14].

The open innovation framework presented by Lichtenthaler and Lichtenthaler [11] includes various types of open innovation and viewpoints of "collaborative innovation," "absorptive capacity," "market orientation." For the success of an open innovation strategy, Lichtenthaler and Lichtenthaler [11] emphasized that firms should have various knowledge capacities to implement it well. Lichtenthaler and Lichtenthaler [11] suggested that open innovation frameworks constitute six knowledge capacities related to internal and external knowledge retention, exploration and exploitation: (1) transformative capacity; (2) connective capacity; (3) inventive capacity; (4) absorptive capacity; (5) innovative capacity; (6) desorptive capacity.

Internal knowledge retention related with transformative capacity is a result of the need to maintain knowledge over time [19]. External knowledge retention related with connective capacity refers to knowledge that is maintained in a firm's interorganizational relationships [5]. Internal knowledge exploration related with inventive capacity refers to generating new knowledge inside the firm [20]. External knowledge exploration related with absorptive capacity describes the acquisition of knowledge from external sources [21]. Internal knowledge exploitation related with innovative capacity describes internal innovation, that is, knowledge application involving a firm's own products [22]. External knowledge exploitation related with desorptive capacity refers to outward knowledge transfer, for example, by means of technology alliances or technology licensing [23].

However, Lichtenthaler and Lichtenthaler [11] did not provide relationships among knowledge capacities and links to performance, despite the fact that these offer diverse knowledge capacities for open innovation. The open innovation framework provides a sufficient analytical perspective to verify the relationships of knowledge capacities and performances. Therefore, this study intends to help in understanding how to generate technological innovation and financial performance through the various knowledge capacities.

\subsection{Transformative, Connective, Inventive, Absorptive Capacity and Technological Innovation Performance}

Transformative capacity is defined as a firm's ability to retain its internal knowledge base [19,24]. In other words, the term "transformative capacity" indicates that knowledge is transformed if firms maintain knowledge over time and reactivate it subsequently [11]. The specific tasks described under this capacity are to select technologies and internally maintain, reactivate and synthesize knowledge [19]. In particular, when required, the ability to reactivate developed technologies over time is important for a firm's technological innovation [24,25].

Some previous studies have shown that transformative capacity can have a positive impact on the technological innovation performance of firms. Adams and Lamont [26] found that transformative capacity, along with absorptive capacity, plays an important role in organizational innovation. Guan et al. [27] revealed that the innovation activities in Chinese manufacturing firms could not be boosted substantially merely through the acquisition of key equipment and apparatus from abroad. They suggested that Chinese firms should develop their technological transformative capacity, as well as their absorptive capacity, in order to foster technology transfer and communications among trading partners. Huang, Lai and Huang [28] explained the role played by transformative 
capacity in the process of inbound open innovation for SMEs through empirical analysis. They found that transformative capacity has a significant mediating role in the relationship between resource complementarity and inbound open innovation. Therefore, based on these previous studies, this study validates the following hypotheses.

Hypothesis 1 (H1). Firm's transformative capacity has a positive influence on technological innovation performance.

In sociology, connective capacity refers to the ability to establish links with other elements and these connections facilitate knowledge access [29]. In the field of strategic management, connective capacity is defined as a firm's ability to retain its external knowledge base through interorganizational relationships such as strategic alliances [30]. Connective capacity includes not only relational capability but also alliance capability, which further ensures access to external knowledge bases [31,32]. However, it does not require inward knowledge transfer. In addition, similar to transformative capacity, connective capacity may comprise both maintaining knowledge in inter-organizational relationships and subsequently reactivating this knowledge from the perspective of dynamic capability [30].

Scholars have shown that connective capacity can have a positive impact on the technological innovation performance of firms. Gulati [5] found that firms can efficiently enjoy specialization in the creation of new knowledge by externally retaining knowledge. Efficient specialization at the knowledge level involves external knowledge retention, because merely transferring knowledge between partners is inefficient. Jeong and Ko [33] and Wang, Chang and Shen [34] found that the ability to build well-developed external connection channels increased the efficacy of inbound open innovation in achieving superior performance. For example, pharmaceutical companies often collaborate with numerous biotechnology firms in one particular field of technology [35]. Over the years, the biotechnology firms' knowledge is externally retained from the perspective of the pharmaceutical firm, which does not immediately internalize the knowledge. However, the pharmaceutical companies have ensured exclusive access to the results of the partners' R\&D in this field by establishing collaboration agreements. This extended knowledge base provides the pharmaceutical firm with the option of accessing the knowledge of various partners. Therefore, in this context, this study examines the following hypothesis.

Hypothesis 2 (H2). Firm's connective capacity has a positive influence on technological innovation performance.

Inventive capacity is defined as a firm's ability to generate new knowledge inside the firm, originating from the perception of particular opportunities [36]. Therefore, inventive capacity is directly linked to technology innovation performance. The creation of new knowledge is usually the outcome of perceiving opportunity or unmet needs for that knowledge. However, new knowledge that can meet the opportunity or unmet need does not appear in the absence of previous knowledge base. That is, the creation of new knowledge is affected by the firm's knowledge base. In this vein, Coombs and Hull [37] argue that knowledge-generating activities within firms are path-dependent. Therefore, inventive capacity can be defined as a firm's internal ability to explore new knowledge in its knowledge base [11].

Specifically, the creation level of new knowledge is determined by the complementarity and substitutability of the firm's knowledge base. Dibiaggio, Nasiriyar and Nesta [38] analyzed whether complementarity and substitutability of knowledge elements are key determinants of the firm's inventive capacity. Using patent data from 1968 to 2002 in the semiconductor industry, they find that the overall level of complementarity between knowledge components positively contributes to firms' inventive capability, whereas the overall level of substitutability between knowledge components generally has the opposite effect. Therefore, this study shows that the inventive capacity is the ability to control the complementarity and substitutability of the enterprise's knowledge base and to create new knowledge. 
Therefore, firm knowledge bases with high complementarity or low substitutability among knowledge elements generally have a positive impact on technological innovation performance by increasing these firms' transformative capacity. On the other hand, firms with a knowledge base with low complementarity and high substitutability among knowledge elements will increase their connective capacity to solve the absence of an internal knowledge source. The findings of this study emphasize that a firm's inventive capacity significantly depends on knowledge base structure and may influence transformative capacity and connective capacity. Drawing from these insights, this study examines the following two hypotheses.

Hypothesis 3-1 (H3-1). Firm's inventive capacity has a positive influence on technological innovation performance.

Hypothesis 3-2 (H3-2). Firm's inventive capacity has an influence on transformative capacity and connective capacity.

Absorptive capacity is defined as a firm's ability to internalize external knowledge for new knowledge [39]. To internalize the knowledge outside, firms clearly need prior related knowledge in their knowledge base [40]. Mowery and Oxley [41] defined absorptive capacity as "a broad set of skills needed to deal with the tacit component of transferred knowledge." Kim [42,43] defined it as the capacity to learn and to solve problems using external knowledge. In this sense, absorptive capacity is the capacity to internalize external knowledge and may positively influence technological innovation performance.

The study by Zahra and George [44] explains the organizational differences required by new knowledge creation by interpreting absorptive capacity from the viewpoint of dynamic capability. They emphasized absorptive capacity "embedded in a firm's routines and processes, making it possible to analyze the stocks and flows of a firm's knowledge" [44]. They suggested that absorptive capacity was constituted as four organizational capabilities: knowledge acquisition, assimilation, transformation and exploitation; and further, was classified into potential and realized capacities. They explained that potential capacity is related to knowledge acquisition and assimilation capabilities, while realized capacity is connected to knowledge transformation and exploitation.

Potential absorptive capacity captures the company's ability to evaluate and acquire external knowledge but does not guarantee the exploitation of this knowledge. On the other hand, realized absorptive capacity is a function of capabilities related to knowledge transformation and exploitation. Realized absorptive capacity reflects the firm's capacity to leverage the knowledge that has been absorbed. Therefore, the firm tries to expand its connections with external organizations to increase its potential absorptive capacity. This implies that the potential absorptive capacity is the driving force for the firm to increase its connective capacity. The realized absorptive capacity also calls for the use of internal knowledge to integrate the knowledge gained from the outside. This leads to the re-creation of existing knowledge in a modified form. Thus, realized absorptive capacity is a driving force to increase the transformative capacity of the firm. Therefore, this study examines the following two hypotheses.

Hypothesis 4-1 (H4-1). Firm's absorptive capacity has a positive influence on technological innovation performance.

Hypothesis 4-2 (H4-2). Firm's absorptive capacity has an influence on transformative capacity and connective capacity.

\subsection{Innovative, Desorptive Capacity, Technology Innovation Performance and Financial Performance}

Innovative capacity is defined as a firm's internal ability to exploit knowledge [11]. It is associated with matching inventions with the context of their final market [39] and refers to the application of knowledge that has been explored and retained inside or outside the firm [21,45]. In general, the birth of state-of-the-art technology is likely to be perceived as the whole of innovation. However, 
Baporikar et al. [46] explained that technological excellence is different from innovative competence. They found by interviewing experts that the concept of innovation capacity is more market-oriented than is technological excellence.

Firms should be capable of adapting to unpredictable environmental conditions with strategic flexibility for markets. This is often achieved by innovative capacity [47]. In other words, innovative capacity enables firms to quickly sense the relevant direction in changes of market circumstances, change their strategic direction and thus make the company's technological innovations fit in the market $[48,49]$. In this sense, Hurley and Hult [50] emphasized that firms need continuous organizational learning in order to establish their market orientation. This means that innovative capacity entails not only monitoring the market but also the ability to pivot the firm's latest technology towards the market through organizational learning.

Therefore, firms with strong innovative capacity might have higher financial performance than those without. Narver and Slater [51] found market orientation through firms' innovative capacities provides a positive influence on their profitability. Kirca, Jayachandran and Bearden [52], through a meta-analysis, argued that market orientation through a firm's innovative capacity has a positive effect on the firm's financial performance, further emphasizing that this relationship is stronger in product companies. Therefore, this study attempts to verify following hypothesis.

\section{Hypothesis 5 (H5). Firm's innovative capacity has a positive influence on financial performance.}

Desorptive capacity is the ability of an organization to transfer the knowledge developed by it to an appropriate organization so that it can be utilized externally. Zytner [53] referred to it as the reverse process of absorbing. Lichtenthaler [23] emphasized that firms' desorptive capacity to apply their knowledge or technology to the knowledge creation process of external organizations is complementary to internal knowledge exploitation. In the open innovation perspective, capturing value through the external commercialization of a firm's internal knowledge or technology is a significant strategy for its competitiveness and business sustainability [54]. Desorptive capacity consists of identifying the opportunities for exploiting external knowledge and transferring that knowledge to the recipient. [23,55]. Further Lichtenthaler and Muethel [56] emphasized that the practice of technology out-licensing includes the ability to sense and seize appropriate recipients and convey knowledge to them.

Desorptive capacity increases firms' financial performance by transferring technology generated by them to external companies. Firms with high desorptive capacity can additively utilize their developed technologies to make new revenue path (e.g., revenue by technology transfer) in addition to existing revenue structure. Lichtenthaler [57] emphasized that the increase of desorptive capacity for outbound open innovation is critical to avoid a firm's potential risks and to capture its financial benefits. Bianchi and Lejarraga [58] found that desorptive capacity positively affects licensing revenues, using data from Spanish manufacturing firms. Kim, Kim and Cho [59] also found that desorptive capacity is a significant variable in moderating the relation between Korean firms' R\&D investment and their financial performance. They concluded that increasing R\&D investment alone is not sufficient to improve corporate performance, which emphasizes the complementary role of desorptive capacity. Therefore, this study examines the following hypothesis.

Hypothesis 6 (H6). Firm's desorptive capacity has a positive influence on financial performance.

New technological innovations increase commercialization capacity classified to innovative capacity and desorptive capacity. First, new technology innovations are an important element, or resource in creating new products and services in the marketplace [60]. While new products and services are not necessarily based on new technological innovations, they can be combined with firm's previous technologies, products and services by creating exploitative search to final market $[45,61]$. In addition, the achievement of technological innovations in company enhances 
its technological competitiveness [62]. Improving technological competitiveness can increase the chances of occupying firm's current markets or bring opportunities in areas that were not previously available [36]. In sum, new technological innovations require the ability to search for products or services that are appropriate for the market, or to expand firm's current markets and capture opportunities in new markets. Therefore, firm's technology innovation performance may improve innovative capacity.

Second, new technology innovations may be utilized by directly outward transferring them in the market. Especially in the biopharmaceutical industry, since the R\&D period is long and huge funds are needed in the process, small and medium-sized enterprises generally tend to relocate their technological innovation achievements to bigger companies than their own to commercialize them $[62,63]$. Firms identify opportunity to exploit new technological innovations through their own formal or informal networks, or by exploring new technology recipient [64]. After the firm identify opportunity of external technology exploitation, it practically has to consider (1) type of value creation such as $R \& D$, manufacturing and marketing; (2) organizational structure related with competitors and eco-system; (3) the extent of firm's know-how transfer to succeed outward technology transfer [65]. Therefore, firm need the ability to identify opportunities for technology transfer and actually implement it. Thus, firm's technology innovation performance may improve desorptive capacity. Therefore, this study attempts to verify following two hypotheses.

Hypothesis 7-1 (H7-1). Firm's technology innovation performance has a positive influence on innovative capacity.

Hypothesis 7-2 (H7-2). Firm's technology innovation performance has a positive influence on desorptive capacity.

The study model and hypotheses are summarized in Figure 1.

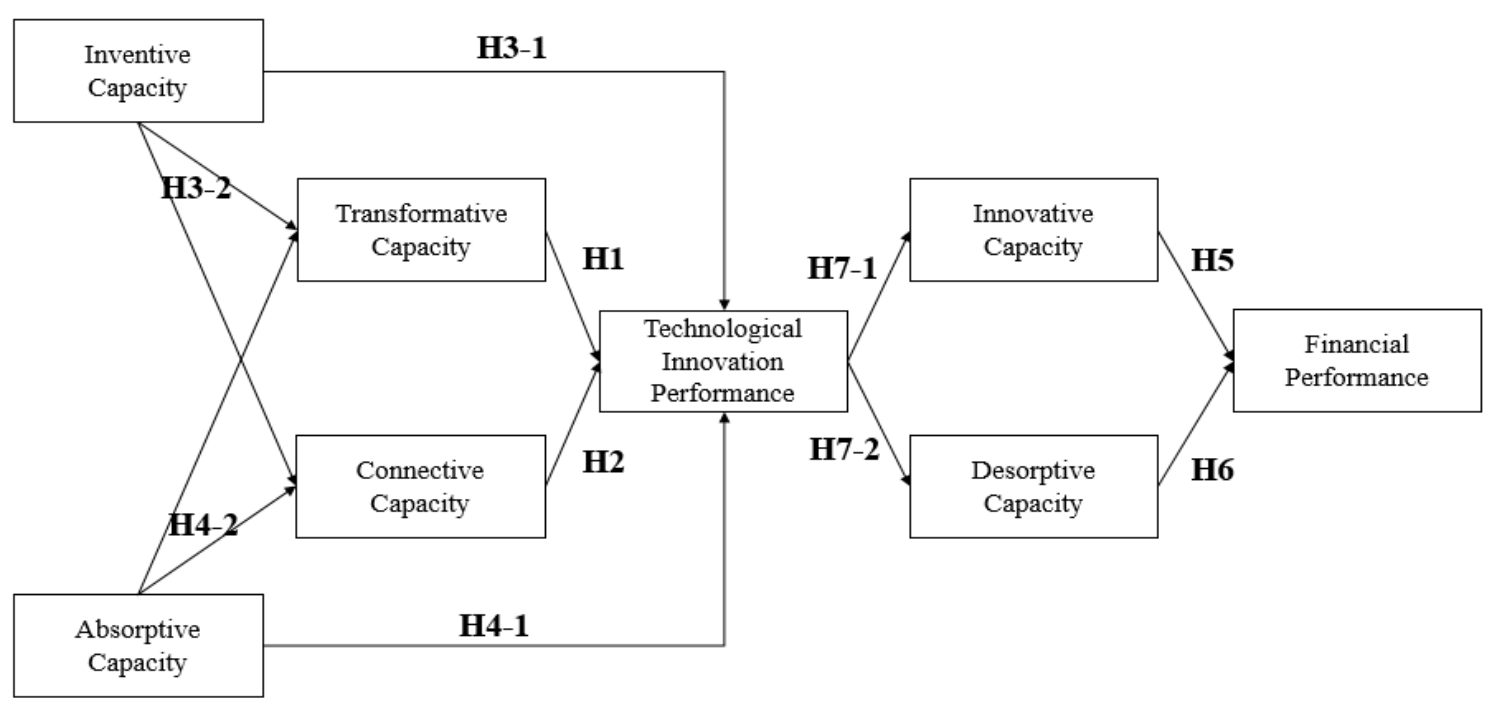

Figure 1. Study model and hypotheses.

\section{Methodology}

\subsection{Data}

The study identified a list of US biopharmaceutical companies that were the subject of the study from Medtrack database and PATSTAT Global data. Medtrack database has the list of global biomedical firms, involving drug, medical device, food companies and so forth, produced by Informa. Medtrack basically provides information about (1) lists of global biomedical firms and their addresses, partially accounting and finance details, products and patents; (2) deal-making in R\&D, manufacturing, 
or marketing. Our focus is biopharmaceutical firms in the US. Therefore, this study picked out 152 listed firms from the Medtrack data. To overcome shortcomings of patent information from Medtrack, the missing information from the PATSTAT Global database were supplemented. The PATSTAT database contains bibliographical and legal status patent data from leading industrialized and developing countries, extracted from the European Patent Office (EPO) databases [66].

This study finally used information secured from 71 US listed biopharmaceutical firms and 407 observations during operations from 2010 to 2016. Biopharmaceutical firms can be categorized into two groups, based on their main focuses of business, according to Willemstein, van der Valk and Meeus [67]: (1) therapeutic product firms; and (2) platform service firms. Therapeutic product firms are companies that actually produce their products and generate profit, while platform service firms are companies that provide R\&D services such as gene sequencing and analysis and clinical trials and so forth, without producing operation. Firms in this study include 42 (59\%) therapeutic product companies and $29(41 \%)$ platform service companies.

\subsection{Variables and Analytical Method}

This study has eight study variables: (1) transformative capacity; (2) connective capacity; (3) inventive capacity; (4) absorptive capacity; (5) technological innovation performance; (6) innovative capacity; (7) desorptive capacity; (8) financial performance. First, transformative capacity represents the ability of companies to retain and reuse their knowledge base. McMillan, Mauri and Halmilton [68] recommended a self-citation indicator as a measure of transformative capacity. Therefore, as a proxy for transformative capacity, this study uses the number of self-citations of a firm's registered patents for patent applications with the USPTO in the fiscal year.

Second, connective capacity represents the ability of a company to gain access to its external knowledge base and to have immediate access to it when needed. Previous studies used the number of alliance partnerships at the organizational level, or the number of backward citations in the knowledge structure, to measure connective capacity $[69,70]$. Though the number of alliance partnerships can be used as an indicator of connective capacity at the organizational level, this study focuses on external knowledge or technologies that are accessible at the knowledge level. Thus, the number of backward citations is used as a measure of connective capacity. But because the number of backward citations contain the number of self-citations, it needs to subtract the number of self-citations that utilize a company's own knowledge base, meaning transformative capacity. In sum, as a proxy for connective capacity, this study uses the number of backward citations minus the number of self-citations of the firm's previously registered patents within its patent applications to the USPTO in the fiscal year.

Third, inventive capacity is the ability of a company to invent new knowledge or technologies, using its knowledge base internally. In general, inventive capacity is directly related to technology innovation performance, so it uses the patent application index [71]. Therefore, inventive capacity is measured as the number of a firm's patent applications to the USPTO (United States Patent and Trademark Office) in a given fiscal year in this study.

Fourth, absorptive capacity is the ability to explore outside knowledge or technologies. In previous studies, R\&D expenditure, $R \& D$ intensity and number of accumulated patent registrations were used as indicators [72,73]. These indicators emphasize that an internal knowledge base should be backed up to utilize external knowledge. This study measures absorptive capacity as the cumulative number of a firm's patent registrations (knowledge base for patent applications) to the USPTO until the end of the fiscal year. Fifth, the number of patent registrations is used to measure technological innovation performance. The number of patent applications, registrations, citations and new products in the biopharmaceutical industry is an important indicator of technological innovation performance [74]. In particular, the number of firm's patent registrations as a proxy for its technological innovation is generalized as an important R\&D performance indicator in the biotechnology industry [75].

Sixth, innovative capacity refers to the ability of a firm to create products or services that have market orientation and can make a value proposition to its customers from its knowledge base. 
Scholars have used indicators of the number of products or services launched to measure innovative capacity [76-78]. Therefore, as a proxy for innovative capacity, this study uses the number of products and services brought to market in the fiscal year.

Seventh, desorptive capacity refers to the ability of a company to generate revenue by making its technology available to external organizations. Previous studies, as indicators of desorptive capacity, have used the number of outward technology transfers $[65,79]$. Thus, this study measures desorptive capacity as the number of outward technology transfers in the fiscal year.

Eighth, the firm's revenue is used to measure financial performance. Previous studies have used revenue or profit as proxies for financial performance. This study focuses on the short-term financial performance of biopharmaceutical firms. Generally, it takes about over 10 years from the beginning of new drug R\&D to start generating positive return (positive profit) [80]. Although firm profit is definitely a valid proxy of financial performance, given that the study period is seven years, it is more reasonable to use revenue as a proxy for short-term financial performance.

In addition, this research included three control variables for (1) firm size; (2) R\&D intensity; (3) business area. The number of employees is used to measure firm size. Generally, the size of firms is proportionally related to their technological innovation and financial performance [81]. The R\&D intensity is typically measured by R\&D expenditures normalized by the size of a firm [82]. Therefore, the more R\&D investment biopharmaceutical firms have, the more likely they are to increase their technological innovation or financial performance. In addition, this study included as a control variable the firm's business area to consider effects according to business differences. Willemstein, van der Valk and Meeus [67] classified biopharmaceutical firms as (1) therapeutic product firms and (2) platform service firms. This study used an indicator for therapeutic product firms for type of business area.

Table 1 describes the variables and their operational definition used in the analytical model.

Table 1. Definition of variables.

\begin{tabular}{|c|c|c|c|}
\hline & ariables & Definitions & Data Source \\
\hline \multirow{2}{*}{$\begin{array}{l}\text { Performance } \\
\text { variables }\end{array}$} & $\begin{array}{l}\text { Technological Innovation } \\
\text { Performance (TIP) }\end{array}$ & $\begin{array}{l}\text { Number of patent registrations with the USPTO in } \\
\text { the fiscal year }\end{array}$ & Medtrack \\
\hline & $\begin{array}{l}\text { Financial Performance } \\
\text { (FP) }\end{array}$ & Firm's total revenues in the fiscal year & Medtrack \\
\hline \multirow{6}{*}{$\begin{array}{c}\text { Knowledge } \\
\text { capacity variables }\end{array}$} & Inventive Capacity (IVC) & $\begin{array}{l}\text { Number of patent applications to the USPTO } \\
\text { (United States Patent and Trademark Office) in the } \\
\text { fiscal year }\end{array}$ & PATSTAT \\
\hline & $\begin{array}{l}\text { Absorptive Capacity } \\
\text { (AC) }\end{array}$ & $\begin{array}{l}\text { Number of cumulative patent registrations with } \\
\text { the USPTO in the fiscal year }\end{array}$ & PATSTAT \\
\hline & $\begin{array}{l}\text { Transformative Capacity } \\
\text { (TC) }\end{array}$ & $\begin{array}{l}\text { Number of self-citations of firm's registered } \\
\text { patents for patents applications to the USPTO in } \\
\text { the fiscal year }\end{array}$ & PATSTAT \\
\hline & $\begin{array}{l}\text { Connective Capacity } \\
\text { (CC) }\end{array}$ & $\begin{array}{l}\text { Number of backward citations minus self-citations } \\
\text { (of firm's registered patents) for patent applications } \\
\text { to the USPTO in the fiscal year }\end{array}$ & PATSTAT \\
\hline & $\begin{array}{l}\text { Innovative Capacity } \\
\text { (INC) }\end{array}$ & $\begin{array}{l}\text { Number of products and services brought to } \\
\text { market in the fiscal year }\end{array}$ & Medtrack \\
\hline & $\begin{array}{l}\text { Desorptive Capacity } \\
\text { (DC) }\end{array}$ & $\begin{array}{l}\text { Number of outward technology transfers in the } \\
\text { fiscal year }\end{array}$ & Medtrack \\
\hline \multirow{3}{*}{ Control variables } & Size & Number of employees & Medtrack \\
\hline & R\&D intensity & Ratio of R\&D expenses to the number of employees & Medtrack \\
\hline & Business area & $\begin{array}{l}1 \text { if the business area of the firm is production of } \\
\text { therapeutic products, } 0 \text { otherwise }\end{array}$ & Medtrack \\
\hline
\end{tabular}

This study constructed a generalized structural equation model (GSEM) based on the open innovation process to verify the study hypotheses, which are the structural relationship and 
influence of six open innovation capacities on technological innovation and financial performance in biopharmaceutical firms. The structural equation model (SEM) is an approach that can simultaneously solve various types of models [83]. In particular, GSEM can support models with generalized response variables (various continuous or count variables) and cover hierarchical structural model [84]. This study focuses on demonstrating the evolutionary (or sequential) relationships between knowledge capacities and performances presented in Lichtenthaler and Lichtenthaler [11]. The application of the hierarchical structural model can explain the direct and indirect effects of sequential actions between six knowledge capacities and two performances. The structural model depicted in Figure 1 is described to equations presented as Equations (1)-(6).

$$
\begin{aligned}
& \mathrm{TC}_{\mathrm{it}}=\beta_{0}+\beta_{1} \mathrm{IVC}_{\mathrm{it}}+\beta_{2} \mathrm{AC}_{\mathrm{it}}+ \\
& \beta_{3} \text { Size }_{i t}+\beta_{4} \text { R\&Dintensity }{ }_{i t}+\beta_{5} \text { Business area }_{i t}+\varepsilon_{\text {it }} \\
& \mathrm{CC}_{\mathrm{it}}=\beta_{0}+\beta_{1} \mathrm{IVC}_{\mathrm{it}}+\beta_{2} \mathrm{AC}_{\mathrm{it}}+ \\
& \beta_{3} \text { Size }_{i t}+\beta_{4} \text { R\&Dintensity }_{\text {it }}+\beta_{5} \text { Business area }_{i t}+\varepsilon_{\text {it }} \\
& \mathrm{TIP}_{\mathrm{it}+2}=\beta_{0}+\beta_{1} \mathrm{IVC}_{\mathrm{it}}+\beta_{2} \mathrm{AC}_{\mathrm{it}}+\beta_{3} \mathrm{TC}_{\mathrm{it}}+\beta_{4} \mathrm{CC}_{\mathrm{it}}+ \\
& \beta_{5} \text { Size }_{i t}+\beta_{6} \text { R\&D intensity }_{\text {it }}+\beta_{7} \text { Business area }_{i t}+\varepsilon_{\text {it }} \\
& \mathrm{INC}_{\mathrm{it}+5}=\beta_{0}+\beta_{1} \mathrm{TIP}_{\mathrm{it}}+ \\
& \beta_{2} \text { Size }_{i t}+\beta_{3} \text { R\&Dintensity }_{\text {it }}+\beta_{4} \text { Business area }_{i t}+\varepsilon_{\text {it }} \\
& \mathrm{DC}_{\mathrm{it}+2}=\beta_{0}+\beta_{1} \mathrm{TIP}_{\mathrm{it}}+ \\
& \beta_{2} \text { Size }_{i t}+\beta_{3} \text { R\&D intensity }_{\text {it }}+\beta_{4} \text { Business area }_{i t}+\varepsilon_{\text {it }} \\
& \mathrm{FP}_{\text {it }}=\beta_{0}+\beta_{1} \mathrm{INC}_{\mathrm{it}}+\beta_{3} \mathrm{DC}_{\mathrm{it}} \\
& \beta_{4} \text { Size }_{i t}+\beta_{5} \text { R\&D intensity }{ }_{i t}+\beta_{6} \text { Business area }_{i t}+\varepsilon_{i t}
\end{aligned}
$$

Equation (3) has two-year lags between inventive, absorptive, transformative, connective capacities and technological innovation performance. Capacity indicators are all related to the patent applications and number of cumulative patent registrations of a company in year $t$ and technological innovation performance is an index related to the number of patent registrations in year $t+2$. There is usually a time gap of two years between the application and registration of a patent [85]. In addition, the number of cumulative patent registrations of a company, which represents absorption capacity in our model, should also be adjusted to the same time as the inventive capacity. Therefore, two years of lag are used in Equation (3). In Equation (4), innovation capacity and technological innovation performance were included in the model with a five-year lag, because they were the results of technological innovation performance to market. A patent registered by the firm (technological innovation performance) requires a process of further development, clinical trials, production and marketing for using as a product or service. There is usually a time gap of five years to complete this process [86]. Therefore, five years of lag are used in Equation (4). In Equation (5), desorptive capacity and technological innovation performance were included in the model with a two-year lag, because they were the results of technological innovation performance to licensing out and this generally takes two years from firm's patent registration, when is generally after the completion of Phase I clinical trials [87]. Therefore, two years of lag are used in Equation (4).

\section{Results and Discussion}

Descriptive statistics and correlation coefficients of variables are shown in Table 2. Apart from desorptive capacity and transformative capacity, desorptive capacity and connective capacity and business area and technological innovation performance, correlations among all variables were significant in Table 2. The estimated results of the GSEM are shown in Table 3. Figure 2 represents the summarized results of this study. 
Table 2. Descriptive statistics and correlations between study variables $(N=407)$.

\begin{tabular}{|c|c|c|c|c|c|c|c|c|c|c|c|c|c|c|c|c|c|c|c|c|c|c|}
\hline \multirow{2}{*}{$\begin{array}{c}\text { Variables } \\
\text { IVC }\end{array}$} & \multirow{2}{*}{$\begin{array}{l}\text { Mean } \\
10.548\end{array}$} & \multirow{2}{*}{$\begin{array}{c}\text { Standard Deviation } \\
25.595\end{array}$} & \multicolumn{2}{|c|}{ IVC } & \multicolumn{2}{|l|}{ AC } & \multicolumn{2}{|c|}{ TC } & \multicolumn{2}{|l|}{$\mathrm{CC}$} & \multicolumn{2}{|c|}{ TIP } & \multicolumn{2}{|c|}{ INC } & \multicolumn{2}{|l|}{ DC } & \multicolumn{2}{|l|}{ FP } & \multicolumn{2}{|l|}{ Size } & \multicolumn{2}{|c|}{ R\&D Intensity } \\
\hline & & & 1.000 & & & & & & & & & & & & & & & & & & & \\
\hline AC & 171.966 & 400.510 & 0.730 & $* * *$ & 1.000 & & & & & & & & & & & & & & & & & \\
\hline TC & 4.575 & 11.990 & 0.228 & $* * *$ & 0.472 & $* * *$ & 1.000 & & & & & & & & & & & & & & & \\
\hline $\mathrm{CC}$ & 19.184 & 30.256 & 0.300 & $* * *$ & 0.568 & $* * *$ & 0.687 & $* * *$ & 1.000 & & & & & & & & & & & & & \\
\hline TIP & 10.582 & 24.530 & 0.859 & $* * *$ & 0.785 & $* * *$ & 0.319 & $* * *$ & 0.406 & $* * *$ & 1.000 & & & & & & & & & & & \\
\hline INC & 5.870 & 14.061 & 0.688 & $* * *$ & 0.845 & $* * *$ & 0.312 & $* * *$ & 0.462 & $* * *$ & 0.753 & $* * *$ & 1.000 & & & & & & & & & \\
\hline DC & 1.268 & 2.633 & 0.173 & $* * *$ & 0.071 & $* *$ & 0.031 & & -0.002 & & 0.202 & $* * *$ & 0.052 & & 1.000 & & & & & & & \\
\hline $\mathrm{FP}^{\mathrm{a}}$ & 4.075 & 10.837 & 0.792 & $* * *$ & 0.922 & $* * *$ & 0.372 & $* * *$ & 0.507 & $* * *$ & 0.828 & $* * *$ & 0.872 & $* * *$ & 0.028 & $* *$ & 1.000 & & & & & \\
\hline Size & 8.206 & 23.328 & 0.822 & $* * *$ & 0.897 & $* * *$ & 0.336 & $* * *$ & 0.476 & $* * *$ & 0.833 & $* * *$ & 0.811 & $* * *$ & 0.024 & $* *$ & 0.938 & $* * *$ & 1.000 & & & \\
\hline$R \& D$ intensity $b$ & 17.432 & 17.944 & -0.157 & $* * *$ & -0.136 & $* * *$ & 0.001 & $* *$ & -0.063 & $*$ & -0.136 & $* * *$ & -0.164 & $* * *$ & -0.009 & $* *$ & -0.161 & $* * *$ & -0.186 & $* * *$ & 1.000 & \\
\hline Business area & 0.590 & 0.492 & 0.086 & $* * *$ & 0.137 & $* * *$ & 0.113 & $*$ & 0.141 & $* * *$ & 0.092 & & 0.116 & $*$ & -0.168 & $* * *$ & 0.142 & $* * *$ & 0.189 & $* * *$ & -0.184 & $* * *$ \\
\hline
\end{tabular}

Table 3. Coefficients estimated by the generalized structural equation model $(N=407)$.

\begin{tabular}{|c|c|c|c|c|c|c|c|c|c|c|c|c|}
\hline \multirow{3}{*}{$\begin{array}{c}\text { Independent Variable } \\
\mathrm{IVC}_{\mathrm{it}}\end{array}$} & \multicolumn{12}{|c|}{ Dependent Variable } \\
\hline & \multirow{2}{*}{\multicolumn{2}{|c|}{$\begin{array}{c}\text { TC }_{\mathbf{i t}} \\
0.010 \\
(0.007)\end{array}$}} & \multicolumn{2}{|c|}{$\mathrm{CC}_{\mathrm{it}}$} & \multicolumn{2}{|c|}{$\mathrm{TIP}_{\mathrm{it}+2}$} & \multicolumn{2}{|c|}{$\mathrm{INC}_{\mathrm{it}+5}$} & \multicolumn{2}{|c|}{$\mathrm{DC}_{\mathrm{it}+2}$} & \multicolumn{2}{|c|}{$\mathrm{FP}_{\mathrm{it}+5}$} \\
\hline & & & $\begin{array}{c}0.020 \\
(0.009)\end{array}$ & + & $\begin{array}{c}0.030 \\
(0.005)\end{array}$ & $* * *$ & & & & & & \\
\hline $\mathrm{AC}_{\mathrm{it}}$ & $\begin{array}{c}0.003 \\
(0.0005)\end{array}$ & $* * *$ & $\begin{array}{c}0.003 \\
(0.0007)\end{array}$ & $* * *$ & $\begin{array}{c}0.001 \\
(0.000)\end{array}$ & $* *$ & & & & & & \\
\hline $\mathrm{TC}_{\text {it }}$ & & & & & $\begin{array}{c}0.018 \\
(0.010) \\
\end{array}$ & + & & & & & & \\
\hline $\mathrm{CC}_{\mathrm{it}}$ & & & & & $\begin{array}{c}0.009 \\
(0.004)\end{array}$ & * & & & & & & \\
\hline $\mathrm{TIP}_{\text {it }}$ & & & & & & & $\begin{array}{c}0.009 \\
(0.004)\end{array}$ & $t$ & $\begin{array}{c}0.032 \\
(0.008)\end{array}$ & $* * *$ & & \\
\hline $\mathrm{INC}_{\text {it }}$ & & & & & & & & & & & $\begin{array}{c}0.246 \\
(0.018) \\
\end{array}$ & $* * *$ \\
\hline $\mathrm{DC}_{\mathrm{it}}$ & & & & & & & & & & & $\begin{array}{c}0.185 \\
(0.066)\end{array}$ & $* * *$ \\
\hline Size $_{\text {it }}$ & $\begin{array}{l}-0.030 \\
(0.008)\end{array}$ & $* * *$ & $\begin{array}{l}-0.030 \\
(0.012)\end{array}$ & $* *$ & $\begin{array}{c}0.001 \\
(0.001)\end{array}$ & & $\begin{array}{c}0.033 \\
(0.005)\end{array}$ & $* * *$ & $\begin{array}{l}-0.042 \\
(0.0116)\end{array}$ & $* * *$ & $\begin{array}{c}0.317 \\
(0.113)\end{array}$ & $* * *$ \\
\hline R\&D intensity ${ }_{i t}$ & $\begin{array}{c}0.001 \\
(0.000)\end{array}$ & $* * *$ & $\begin{array}{c}0.001 \\
(0.000)\end{array}$ & $* * *$ & $\begin{array}{c}0.001 \\
(0.000) \\
\end{array}$ & $* * *$ & $\begin{array}{l}-0.001 \\
(0.000)\end{array}$ & $* * *$ & $\begin{array}{l}-0.001 \\
(0.000)\end{array}$ & $* * *$ & $\begin{array}{c}0.001 \\
(0.008)\end{array}$ & \\
\hline Business area $_{i t}$ & $\begin{array}{c}0.410 \\
(0.200)\end{array}$ & $*$ & $\begin{array}{c}0.530 \\
(0.230)\end{array}$ & $*$ & $\begin{array}{l}-0.312 \\
(0.155)\end{array}$ & * & $\begin{array}{l}-0.471 \\
(0.145)\end{array}$ & $* * *$ & $\begin{array}{l}-0.392 \\
(0.218)\end{array}$ & & $\begin{array}{l}-0.288 \\
(0.329)\end{array}$ & \\
\hline
\end{tabular}




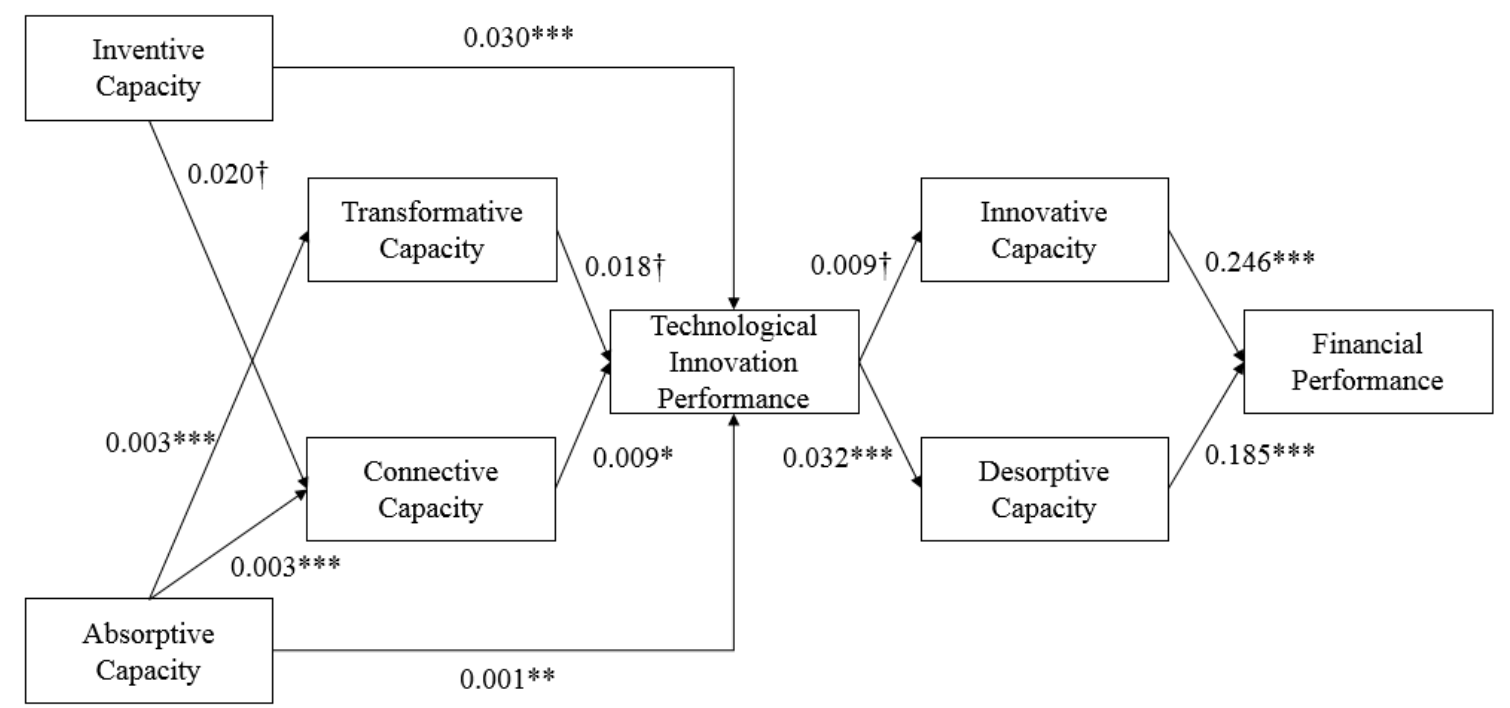

Figure 2. The structural relationships and influences between firms' six open innovation capacities and technological innovation and financial performance in the biopharmaceutical industry, ${ }^{* * *} p<0.001$, ** $p<0.01, * p<0.05,+p<0.1$.

First, in the relationship between control variables and dependent variables, the size variable has positive effects on innovation capacity and financial performance $(p<0.001$ in all relationships) but negative effects on transformative capacity, connective capacity and desorptive capacity $(p<0.001$, $p<0.01$ and $p<0.001$, respectively). In addition, the results show that $R \& D$ intensity has a positive impact on transformative capacity, connective capacity and technological innovation performance $(p<0.001$ in all relationships) and a negative impact on innovative capacity and desorptive capacity $(p<0.001$ in all relationships). Business area of therapeutic product has a positive impact on transformative capacity and connective capacity $(p<0.1$ in all relationships) and has a negative impact on technological innovation performance and innovative capacity $(p<0.1$ and $p<0.001$, respectively).

This study confirms that transformative, connective, inventive and absorptive capacity all have a positive influence on technological innovation performance $(p<0.1, p<0.05, p<0.001$ and $p<0.01$, respectively), supporting Hypotheses 1, 2, 3-1 and 4-1. This study also found that inventive capacity positively influences connective capacity and absorptive capacity positively affects transformative capacity and connective capacity $(p<0.1, p<0.001$ and $p<0.001$, respectively), partially supporting Hypothesis 3-2 and completely supporting Hypothesis 4-2. Furthermore, this study found that inventive capacity has a mediating effect in increasing technological innovation performance by promoting connective capacity and absorptive capacity also has an indirect influence on technological innovation performance by enhancing transformative capacity and connective capacity. The total direct effect of transformative, connective, inventive and absorptive capacity on technological innovation performance is 0.058 , while the total indirect effect of inventive and absorptive capacity is 0.0003 .

The results of this study prove that knowledge retention and exploration capacities both inside and outside of firm are important knowledge competencies for the firm's technological innovation performance. Transformative and connective capacity directly influenced technological innovation performance, as did inventive capacity and absorptive capacity. It means that the results of our research confirm the role of various knowledge capacities in new knowledge creation, that is, in technology innovations. In sum, our findings demonstrate that knowledge capacities related to knowledge retention and exploration, as set out in Lichtenthaler and Lichtenthaler [11], work in the new knowledge creation process for biopharmaceutical firms. 
Furthermore, the results of this study help in understanding the flow of knowledge capacities for technological innovation performance. The findings show that inventive capacity improves transformative capacity, which is the ability to transform knowledge held within the firm. This study also showed that absorptive capacity plays a role in improving not only transformative capacity but also connective capacity, which is the ability to maintain the linkage of external knowledge. This implies that there are three virtuous paths for technology innovation performance in the biopharmaceutical industry of (1) inventive capacity-transformative capacity-technological innovation performance; (2) absorptive capacity-transformative capacity-technological innovation performance; and (3) absorptive capacity-connective capacity-technological innovation performance.

The study also found direct positive effects of innovative capacity and desorptive capacity on financial performance ( $p<0.001$ in all relationships), supporting Hypotheses 5 and 6 . In addition, technological innovation performance improves the innovative capacity and desorptive capacity $(p<0.1$, $p<0.001$, respectively) and indirectly affects the financial performance, supporting Hypotheses $7-1$ and $7-2$. In sum, the total direct effect on financial performance from innovative capacity and desorptive capacity is 0.431 and total indirect influence of technological innovation performance is 0.008 .

The results of this study imply that internal or external knowledge exploitation capacities towards the market are critical knowledge competencies for firms' financial performance. In addition, new knowledge creations (technological innovations) are an important resource for improving the company's innovative capacity and desorptive capacity. Firms judge whether they exploit new technological innovations internally or externally using innovative capacity and desorptive capacity. Firms generally develop their new technological innovations through innovative capacity if they have complementary resources and relevant core competencies in order to create market-oriented products and services [88]. On the other hand, if they lack the resources and capabilities to complement new technological innovations, or identify opportunities for external exploitation of technology innovations, firms may seek external organizations suitable and transfer them through their desorptive capacity [23]. This study's findings confirm that there are two ways-through innovative capacity and desorptive capacity—-for firms to drive revenue from technological innovations in the biopharmaceutical industry.

\section{Conclusions}

This study examined the structural relationships and influences on technological innovation and financial performances, of six knowledge capacities: (1) transformative; (2) connective; (3) inventive; (4) absorptive; (5) innovative; and (6) desorptive capacities, as proposed by Lichtenthaler and Lichtenthaler [11]. The research sought to separate direct effects and indirect effects of knowledge capacities on performances and further to understand knowledge flows by clarifying the relationships between knowledge capacities and performances through a structural model. The results of this study are as follows, particularly in biopharmaceutical industry: first, it confirmed direct effects of transformative and connective capacities and direct and indirect effects of inventive and absorptive capacities on technological innovation performance. Second, it demonstrated direct effects of innovative capacity and desorptive capacity on financial performance and the indirect effect of technological innovations on financial performance, which is established through innovative capacity and desorptive capacity.

This study provides two managerial implications for firm's knowledge managers, particularly biopharmaceutical industry. First, firms should improve their overall transformative, connective, inventive and absorptive capacities to promote technological innovation performance (patent). These capacities work in combination for technological innovation performance. It is possible for a firm to make a mistake that is biased towards internal exploration innovation, the creation of technological innovation performance by inventive capacity, or external exploration innovation, the creation of technological innovation performance by absorptive capacity. Firms should maximize their technological innovation performance by exploratory innovation with balanced knowledge management capability between inventive capacity and absorptive capacity. In addition, firms must 
develop their ability to preserve their knowledge base and avoid it being made obsolete, by internally transforming and externally connecting knowledge. Furthermore, firms strive to recognize and access their internal or external knowledge bases so that their knowledge exploration capacities, that is, inventive capacity and absorptive capacities, can form a virtuous cycle structure that drives transformative and connective capacities.

Second, firms should improve innovative capacity and desorptive capacity and strive to create technological innovations to promote financial performance (revenue). The results of this study clearly demonstrated that there are direct effects of innovative capacity and desorptive capacity on financial performance and indirect effect of technological innovation performance through enhancing innovative capacity and desorptive capacity; that is, there are two paths from technological innovation performance to financial performance. This means that firms should select technology innovations that can be developed internally into products and services that fit the market and that can be developed by outside organizations to utilize them and help the firm's revenue. Therefore, firms should keep in mind that there are two ways to turn technology innovation performance into financial performance and utilize both methods appropriately. In practice, firm's knowledge managers need to be trained and consulted on market pivoting, technology commercialization, technology transfer and so forth, to improve financial performance through innovative capacity and desorptive capacity.

Despite providing various contributions to structural relationships and influences between various knowledge capacities for open innovation and performances, this study has limitations due to restriction of data collection. The results of this study use a variety of indicators such as indicators related to patents, the number of products or services, the number of technology transfers and revenue of the firm but more diverse indicators can be utilized to provide information on subtle differences according to them in future studies. For example, despite the individual studies about each knowledge capacity, there is a lack of studies on proxy discovery that reveal knowledge capacities for open innovation. In addition, although the number of patent registrations and revenues are used as performance proxies in this study, using the other qualitative aspects (e.g., the number of family patents, the number of patent claims) of patents to measure the technological innovation performance and the profit aspects for the financial performance measurement can also be considered. This study suggests that these limitations will be complemented by future studies to demonstrate the various relationships among knowledge capacities, or between knowledge capacities and performances related to open innovation and provides useful implications for firm knowledge managers.

Author Contributions: K.S., E.K. and E.J. worked together and significantly contributed to this paper; K.S. designed this study and contributed to the literature review, study modelling and writing; and E.K. contributed to the literature review and data curation; and E.J. implemented and evaluated the analytical model. All authors discussed the implications and approved the final manuscript.

Funding: The funding for this study was supported by Korea Institute of Science and Technology Information (KISTI).

Acknowledgments: This study was conducted with the help of (1) The International Science and Business Belt Program through the Ministry of Science, ICT and Future Planning (2016K000282), Republic of Korea; and (2) the Medical Research Information Center of the National Research Foundation through the Ministry of Science and ICT (2018R1A6A6040880), Republic of Korea.

Conflicts of Interest: The authors declare no conflicts of interest.

\section{References}

1. Chesbrough, H. Open Innovation; Harvard Business School Press: Cambridge, MA, USA, 2003.

2. Galende, J. Analysis of technological innovation from business economics and management. Technovation 2006, 26, 300-311. [CrossRef]

3. Yu, C.; Zhang, Z.; Lin, C.; Wu, Y.J. Knowledge Creation Process and Sustainable Competitive Advantage: The Role of Technological Innovation Capabilities. Sustainability 2017, 9, 2280. [CrossRef]

4. Cassiman, B.; Veugelers, R. In search of complementarity in innovation strategy: Internal R\&D and external knowledge acquisition. Manag. Sci. 2006, 52, 68-82. 
5. Gulati, R. Network location and learning: The influence of network resources and firm capabilities on alliance formation. Strateg. Manag. J. 1999, 20, 397-420. [CrossRef]

6. Andersen, P.H.; Drejer, I. Systemic innovation in a distributed network: The case of Danish wind turbines, 1972-2007. Strateg. Organ. 2008, 6, 13-46. [CrossRef]

7. Nonaka, I.; Takeuchi, H. The Knowledge-Creating Company: How Japanese Companies Create the Dynamics of Innovation; Oxford University Press: Oxford, UK, 1995.

8. Argote, L.; McEvily, B.; Reagans, R. Managing knowledge in organizations: An integrative framework and review of emerging themes. Manag. Sci. 2003, 49, 571-582. [CrossRef]

9. Bogner, W.C.; Bansal, P. Knowledge management as the basis of sustained high performance. J. Manag. Stud. 2007, 44, 165-188. [CrossRef]

10. Nonaka, I.; Byosiere, P.; Borucki, C.C.; Konno, N. Organizational knowledge creation theory: A first comprehensive test. Int. Bus. Rev. 1994, 3, 337-351. [CrossRef]

11. Lichtenthaler, U.; Lichtenthaler, E. A capability-based framework for open innovation: Complementing absorptive capacity. J. Manag. Stud. 2009, 46, 1315-1338. [CrossRef]

12. Yun, J.J.; Won, D.; Park, K. Dynamics from open innovation to evolutionary change. J. Open Innov. Technol. Market Complex. 2016, 2, 7. [CrossRef]

13. Pisano, G.P. Science Business: The Promise, the Reality, and the Future of Biotech; Harvard Business Press: Cambridge, MA, USA, 2006.

14. Martín-de Castro, G. Knowledge management and innovation in knowledge-based and high-tech industrial markets: The role of openness and absorptive capacity. Ind. Mark. Manag. 2015, 47, 143-146. [CrossRef]

15. Nonaka, I. A dynamic theory of organizational knowledge creation. Organ. Sci. 1994, 5, 14-37. [CrossRef]

16. Nonaka, I.; Toyama, R. The knowledge-creating theory revisited: Knowledge creation as a synthesizing process. Knowl. Manag. Res. Pract. 2003, 1, 2-10. [CrossRef]

17. Barney, J. Firm resources and sustained competitive advantage. J. Manag. 1991, 17, 99-120. [CrossRef]

18. Gassmann, O.; Daiber, M.; Enkel, E. The role of intermediaries in cross-industry innovation processes. RED Manag. 2011, 41, 457-469.

19. Garud, R.; Nayyar, P.R. Transformative capacity: Continual structuring by intertemporal technology transfer. Strateg. Manag. J. 1994, 15, 365-385. [CrossRef]

20. Smith, K.G.; Collins, C.J.; Clark, K.D. Existing knowledge, knowledge creation capability, and the rate of new product introduction in high-technology firms. Acad. Manag. J. 2005, 48, 346-357. [CrossRef]

21. Lane, P.J.; Koka, B.R.; Pathak, S. The reification of absorptive capacity: A critical review and rejuvenation of the construct. Acad. Manag. Rev. 2006, 31, 833-863. [CrossRef]

22. Brown, S.L.; Eisenhardt, K.M. Product development: Past research, present findings, and future directions. Acad. Manag. Rev. 1995, 20, 343-378. [CrossRef]

23. Lichtenthaler, U. The drivers of technology licensing: An industry comparison. Calif. Manag. Rev. 2007, 49, 67-89. [CrossRef]

24. Marsh, S.J.; Stock, G.N. Creating dynamic capability: The role of intertemporal integration, knowledge retention, and interpretation. J. Prod. Innov. Manag. 2006, 23, 422-436. [CrossRef]

25. Pandza, K.; Holt, R. Absorptive and transformative capacities in nanotechnology innovation systems. J. Eng. Technol. Manag. 2007, 24, 347-365. [CrossRef]

26. Adams, G.L.; Lamont, B.T. Knowledge management systems and developing sustainable competitive advantage. J. Knowl. Manag. 2003, 7, 142-154. [CrossRef]

27. Guan, J.C.; Mok, C.K.; Yam, R.C.; Chin, K.S.; Pun, K.F. Technology transfer and innovation performance: Evidence from Chinese firms. Technol. Forecast. Soc. Chang. 2006, 73, 666-678. [CrossRef]

28. Huang, H.C.; Lai, M.C.; Huang, W.W. Resource complementarity, transformative capacity, and inbound open innovation. J. Bus. Ind. Mark. 2015, 30, 842-854. [CrossRef]

29. Luhmann, N. Social Systems; Stanford University Press: Stanford, CA, USA, 1995.

30. Grant, R.M.; Baden-Fuller, C. A knowledge accessing theory of strategic alliances. J. Manag. Stud. 2004, 41, 61-84. [CrossRef]

31. Lorenzoni, G.; Lipparini, A. The leveraging of interfirm relationships as a distinctive organizational capability: A longitudinal study. Strateg. Manag. J. 1999, 20, 317-338. [CrossRef]

32. Kale, P.; Singh, H. Building firm capabilities through learning: The role of the alliance learning process in alliance capability and firm-level alliance success. Strateg. Manag. J. 2007, 28, 981-1000. [CrossRef] 
33. Jeong, H.J.; Ko, Y. Configuring an alliance portfolio for eco-friendly innovation in the car industry: Hyundai and Toyota. J. Open Innov. Technol. Market Complex. 2016, 2, 24. [CrossRef]

34. Wang, C.H.; Chang, C.H.; Shen, G.C. The effect of inbound open innovation on firm performance: Evidence from high-tech industry. Technol. Forecast. Soc. Chang. 2015, 99, 222-230. [CrossRef]

35. Zhang, J.; Baden-Fuller, C.; Mangematin, V. Technological knowledge base, R\&D organization structure and alliance formation: Evidence from the biopharmaceutical industry. Res. Policy 2007, 36, 515-528.

36. Shane, S. Prior knowledge and the discovery of entrepreneurial opportunities. Organ. Sci. 2000, 11, 448-469. [CrossRef]

37. Coombs, R.; Hull, R. Knowledge management practices' and path-dependency in innovation. Res. Policy 1998, 27, 237-253. [CrossRef]

38. Dibiaggio, L.; Nasiriyar, M.; Nesta, L. Substitutability and complementarity of technological knowledge and the inventive performance of semiconductor companies. Res. Policy 2014, 43, 1582-1593. [CrossRef]

39. Cohen, W.M.; Levinthal, D.A. Absorptive capacity: A new perspective on learning and innovation. Adm. Sci. Q. 1990, 35, 128-152. [CrossRef]

40. Jansen, J.J.; Van Den Bosch, F.A.; Volberda, H.W. Managing potential and realized absorptive capacity: How do organizational antecedents matter? Acad. Manag. J. 2005, 48, 999-1015. [CrossRef]

41. Mowery, D.C.; Oxley, J.E. Inward technology transfer and competitiveness: The role of national innovation systems. Camb. J. Econ. 1995, 19, 67-93.

42. Kim, L. From Imitation to Innovation: The Dynamics of Korea's Technological Learning; Harvard Business School Press: Cambridge, MA, USA, 1997.

43. Kim, L. Crisis construction and organizational learning: Capability building in catching-up at Hyundai Motor. Organ. Sci. 1998, 9, 506-521. [CrossRef]

44. Zahra, S.A.; George, G. Absorptive capacity: A review, reconceptualization, and extension. Acad. Manag. Rev. 2002, 27, 185-203. [CrossRef]

45. Khilji, S.E.; Mroczkowski, T.; Bernstein, B. From invention to innovation: Toward developing an integrated innovation model for biotech firms. J. Prod. Innov. Manag. 2006, 23, 528-540. [CrossRef]

46. Baporikar, N.; Berber, A.; Brás, F.; Dornelas, J.; Ferreira, A.P.; Hurni, D.; Kunz, C.; Liana, P.; Laranja, M.; Lubawa, G.; et al. Innovation Management: In Research and Industry; Walter de Gruyter GmbH \& Co KG: Berlin, Germany, 2015.

47. Tamayo-Torres, I.; Ruiz-Moreno, A.; Verdú, A.J. The moderating effect of innovative capacity on the relationship between real options and strategic flexibility. Ind. Mark. Manag. 2010, 39, 1120-1127. [CrossRef]

48. Atuahene-Gima, K.; Ko, A. An empirical investigation of the effect of market orientation and entrepreneurship orientation alignment on product innovation. Organ. Sci. 2001, 12, 54-74. [CrossRef]

49. Han, J. Exploitation of architectural knowledge and innovation. J. Open Innov. Technol. Market Complex. 2017, 3, 15. [CrossRef]

50. Hurley, R.F.; Hult, G.T.M. Innovation, market orientation, and organizational learning: An integration and empirical examination. J. Mark. 1998, 62, 42-54. [CrossRef]

51. Narver, J.C.; Slater, S.F. The effect of a market orientation on business profitability. J. Mark. 1990, 54, $20-35$. [CrossRef]

52. Kirca, A.H.; Jayachandran, S.; Bearden, W.O. Market orientation: A meta-analytic review and assessment of its antecedents and impact on performance. J. Mark. 2005, 69, 24-41. [CrossRef]

53. Zytner, R.G. Adsorption-desorption of trichloroethylene in granular media. Water Air Soil Pollut. 1992, 65, 245-255. [CrossRef]

54. Vac, C.S.; Fitiu, A. Building Sustainable Development through Technology Transfer in a Romanian University. Sustainability 2017, 9, 2042. [CrossRef]

55. Rivette, K.G.; Kline, D. Rembrandts in the Attic: Unlocking the Hidden Value of Patents; Harvard Business Press: Cambridge, MA, USA, 2000.

56. Lichtenthaler, U.; Muethel, M. Retracted: The impact of family involvement on dynamic innovation capabilities: Evidence from German manufacturing firms. Entrep. Theory Pract. 2012, 36, 1235-1253. [CrossRef]

57. Lichtenthaler, U. A note on outbound open innovation and firm performance. RED Manag. 2015, 45, 606-608.

58. Bianchi, M.; Lejarraga, J. Learning to license technology: The role of experience and workforce's skills in Spanish manufacturing firms. RED Manag. 2016, 46, 691-705. 
59. Kim, H.; Kim, Y.; Cho, K. The effect of research and development investment and desorptive capacity on firm performance. Asian J. Technol. Innov. 2014, 22, 252-267. [CrossRef]

60. Riahi-Belkaoui, A. Intellectual capital and firm performance of US multinational firms: A study of the resource-based and stakeholder views. J. Intellect. Cap. 2003, 4, 215-226. [CrossRef]

61. Gupta, A.K.; Smith, K.G.; Shalley, C.E. The interplay between exploration and exploitation. Acad. Manag. J. 2006, 49, 693-706. [CrossRef]

62. Teece, D.J. Capturing value from knowledge assets: The new economy, markets for know-how, and intangible assets. Calif. Manag. Rev. 1998, 40, 55-79. [CrossRef]

63. Whitehead, B.; Jackson, S.; Kempner, R. Managing generic competition and patent strategies in the pharmaceutical industry. J. Intellect. Prop. Law Pract. 2008, 3, 226-235. [CrossRef]

64. Müller-Seitz, G. Absorptive and desorptive capacity-related practices at the network level-the case of SEMATECH. RED Manag. 2012, 42, 90-99.

65. Ziegler, N.; Ruether, F.; Bader, M.A.; Gassmann, O. Creating value through external intellectual property commercialization: A desorptive capacity view. J. Technol. Transf. 2013, 38, 930-949. [CrossRef]

66. PATSTAT EPO PASTAT Database. Available online: https://www.epo.org/searching-forpatents/business/ patstat.html\#tab-1 (accessed on 15 June 2018).

67. Willemstein, L.; van der Valk, T.; Meeus, M.T. Dynamics in business models: An empirical analysis of medical biotechnology firms in the Netherlands. Technovation 2007, 27, 221-232. [CrossRef]

68. Steven McMillan, G.; Mauri, A.; Halmilton, R.D. The impact of publishing and patenting activities on new product development and firm performance: The case of the US pharmaceutical industry. Int. J. Innov. Manag. 2003, 7, 213-221. [CrossRef]

69. Mudambi, S.M.; Tallman, S. Make, buy or ally? Theoretical perspectives on knowledge process outsourcing through alliances. J. Manag. Stud. 2010, 47, 1434-1456. [CrossRef]

70. Von Wartburg, I.; Teichert, T.; Rost, K. Inventive progress measured by multi-stage patent citation analysis. Res. Policy 2005, 34, 1591-1607. [CrossRef]

71. Lubango, L.M.; Pouris, A. Industry work experience and inventive capacity of South African academic researchers. Technovation 2007, 27, 788-796. [CrossRef]

72. Deeds, D.L. The role of R\&D intensity, technical development and absorptive capacity in creating entrepreneurial wealth in high technology start-ups. J. Eng. Technol. Manag. 2001, 18, $29-47$.

73. Shin, K.; Kim, S.J.; Park, G. How does the partner type in R\&D alliances impact technological innovation performance? A study on the Korean biotechnology industry. Asia Pac. J. Manag. 2016, 33, 141-164.

74. Kleinknecht, A.; Van Montfort, K.; Brouwer, E. The non-trivial choice between innovation indicators. Econ. Innov. New Technol. 2002, 11, 109-121. [CrossRef]

75. Kang, K.N.; Park, H. Influence of government R\&D support and inter-firm collaborations on innovation in Korean biotechnology SMEs. Technovation 2012, 32, 68-78.

76. McGrath, R.G. Exploratory learning, innovative capacity, and managerial oversight. Acad. Manag. J. 2001, 44, $118-131$.

77. Koc, T.; Ceylan, C. Factors impacting the innovative capacity in large-scale companies. Technovation 2007, 27, 105-114. [CrossRef]

78. Lemon, M.; Sahota, P.S. Organizational culture as a knowledge repository for increased innovative capacity. Technovation 2004, 24, 483-498. [CrossRef]

79. Lichtenthaler, U.; Lichtenthaler, E. Technology transfer across organizational boundaries: Absorptive capacity and desorptive capacity. Calif. Manag. Rev. 2010, 53, 154-170. [CrossRef]

80. Grabowski, H.; Vernon, J. A new look at the returns and risks to pharmaceutical R\&D. Manag. Sci. 1990, 36, 804-821.

81. Baum, J.A.; Calabrese, T.; Silverman, B.S. Don't go it alone: Alliance network composition and startups' performance in Canadian biotechnology. Strateg. Manag. J. 2000, 21, 267-294. [CrossRef]

82. Hall, L.A.; Bagchi-Sen, S. A study of R\&D, innovation, and business performance in the Canadian biotechnology industry. Technovation 2002, 22, 231-244.

83. Anderson, J.C.; Gerbing, D.W. Structural equation modeling in practice: A review and recommended two-step approach. Psychol. Bull. 1988, 103, 411-423. [CrossRef]

84. Skrondal, A.; Rabe-Hesketh, S. Generalized Latent Variable Modeling: Multilevel, Longitudinal, and Structural Equation Models; CRC Press: Boca Raton, FL, USA, 2004. 
85. Ernst, H. Patent applications and subsequent changes of performance: Evidence from time-series cross-section analyses on the firm level. Res. Policy 2001, 30, 143-157. [CrossRef]

86. Bloom, N.; Van Reenen, J. Patents, real options and firm performance. Econ. J. 2002, 112, C97-C116. [CrossRef]

87. Lerner, J.; Merges, R.P. The control of technology alliances: An empirical analysis of the biotechnology industry. J. Ind. Econ. 1998, 46, 125-156. [CrossRef]

88. Cappa, F.; Del Sette, F.; Hayes, D.; Rosso, F. How to deliver open sustainable innovation: An integrated approach for a sustainable marketable product. Sustainability 2016, 8, 1341. [CrossRef]

(C) 2018 by the authors. Licensee MDPI, Basel, Switzerland. This article is an open access article distributed under the terms and conditions of the Creative Commons Attribution (CC BY) license (http:/ / creativecommons.org/licenses/by/4.0/). 